УДК 343.14

DOI https://doi.org/10.32849/2663-5313/2020.6.40

Любомир Лоневсвкий, аспірант кафедри оперативно-розшукової діяльності факультету № 2

Інституту з підготовки фахівців для підрозділів Національної полічії

Львівського державного університету внутрішніх справ

\title{
ВИМОГИ ДО РЕЗУЛЬТАТІВ ОПЕРАТИВНО- РОЗШУКОВОЇ ДІЯЛЬНОСТІ ДЛЯ ЇХ ВИКОРИСТАННЯ ПІД ЧАС ДОСУДОВОГО РОЗСЛІДУВАННЯ УХИЛЕНЬ ВІД СПЛАТИ ПОДАТКІВ, ЗБОРІВ (ОБОВ'ЯЗКОВИХ ПЛАТЕЖІВ)
}

У статті на підставі осмислення потреб практики розкриття та розслідування ухилень від сплати податків, зборів (обов'язкових платежів), нормативно-правової регламентації оперативнорозиукової діяльності оперативних підрозділів податкової міліиії, зокрема ї функиіонального призначення у кримінальному провадженні, а також умов, у яких відбувається формування джерел фактичних даних про обставини подї злочинів, які визначені нормами КПК України 2012 року, виділені та описані вимоги до результатів оперативно-розшукової діяльності для їх використання під час досудового розслідування ухилень від сплати податків, зборів (обов'язкових платежів). Визначено, що матеріалами оперативно-розшукової діяльності, які можуть бути визнані документами - джерелами доказів у кримінальних провадженнях за ст. 212 КК України, $є$ протоколи оперативно-розшукових заходів з додатками до них, документи, одержані в рамках міжнародного співробітниитва у сфері оперативно-розшукової діяльності, та акти податкових перевірок, проведених на підставі даних оперативно-розшукової діяльності податкової міліиії. Інші документи, які були одержані в рамках провадження по оперативно-розшуковій справі, можуть виступати джерелами орієнтуючої інформачії для проведення прочесуальних дій під час досудового розслідування иих злочинів. Констатовано, що для того щоб матеріали оперативно-розшукової діяльності могли бути використані в доказуванні у кримінальному провадженні: 1) вони мають бути зібрані оперативними підрозділами з дотриманням вимог Закону «Про оперативно-розшукову діяльність» та КПК України; 2) у них мають бути зафіксовані фактичні дані про готування, вчинення ухилення від сплати податків, зборів (обов'язкових платежів) окремими особами та групами осіб; 3) відомості про факти, які містяться у матеріалах оперативно-розшукової діяльності, мають бути перевірені та підтверджені проведенням слідчих (розшукових), негласних слідчих (розшукових) та інших процесуальних дій під час досудового розслідування злочину, передбаченого ст. 212 КК України; 4) матеріали оперативнорозшукової діяльності для використання їх у доказуванні мають бути обов'язково розсекречені.

Ключові слова: результати оперативно-розшукової діяльності, використання результатів оперативно-розшукової діяльності, досудове розслідування злочинів, докази, доказування, ухилення від сплати податків, зборів (обов'язкових платежів).

Постановка проблеми. Осмислення потреб практики розкриття та розслідування злочинів, нормативно-правової регламентації оперативно-розшукової діяльності (далі ОРД), зокрема iï функціонального призначення у кримінальному провадженні, а також умов, у яких відбувається формування джерел даних про обставини події злочинів призвело до констатації цілим рядом науковців того, що результатами ОРД є не просто фактичні дані про події, осіб, що мають оперативний інтерес, а й значення для доказування у кримінальному процесі. Причому на фоні значного наукового доробку щодо загальних питань використання у кримінальному провадженні результатів ОРД спостерігається недостатнє дослідження особливостей використання результатів ОРД під час досудового розслідування окремих різновидів злочинів, зокрема ухилень від сплати податків, зборів (обов'язкових платежів).

Аналіз останніх досліджень і публікацій. Аналіз літературних джерел дозволяє виділити роботи К. В. Антонова, А. Я. Алексеєва, В. В. Вапнярчука, Ю. М. Грошевого, О. Ф. Долженкова, С. А. Кіріченка, 
О. І. Козаченка, В.А. Колесника, С.С. Кудінова, А. В. Мовчана, Д. Й. Никифорчука, М. А. Погорецького, В. В. Шендрика, М. Є. Шумила та інших, які містять науковий доробок із загальних питань використання результатів ОРД у кримінальному провадженні, та роботи А. Ю. Бистрова, С. В. Лукашевича, В. В. Лисенка, Ю. О. Мінасова, К. О. Пірцхалави, Д. Г. Сагайдака, В. Г. Сидоренка, Г. П. Цимбал, П. В. Цимбала, В. В. Топчія, Г. Л. Чигриної та інших, у яких приділялася увага особливостям використання таких результатів під час досудового розслідування ухилень від сплати податків, зборів (обов'язкових платежів). Водночас поза рамками вивчених нами досліджень залишилися питання параметрів, яким мають відповідати результати ОРД для використання їх під час досудового розслідування злочинів, передбачених у ст. 212 КК України, з урахуванням положень КПК України 2012 року та чинної редакції Закону України «Про оперативнорозшукову діяльність».

Мета статті - визначити комплекс вимог, яким мають відповідати відомості, матеріальні об'єкти, одержані під час провадження по оперативно-розшуковим справам щодо ухилень від сплати податків, зборів (обов'язкових платежів) для їх використання під час досудового розслідування по кримінальним провадженням щодо цих злочинів.

Виклад основного матеріалу. Використання результатів ОРД у кримінальному провадженні вже тривалий час виступає предметом досліджень, які проводилися як із позицій теорії ОРД, так і з позицій кримінального процесу та криміналістики. Натепер у цих галузях наукових знань домінує концептуальний підхід до визначення результатів ОРД через денотат «матеріали ОРД». Відбулося це внаслідок тривалих наукових розвідок та дискусій на стику теорій ОРД та доказування у кримінальному провадженні, які призвели до усвідомлення того, що результати ОРД можуть стати придатними для використання у кримінальному процесі тільки тоді, коли вони будуть відповідати вимогам процесуальної форми фіксування результатів кримінальної процесуальної діяльності. Щодо цього М. А. Погорецький слушно вказує, що матеріали ОРД, з одного боку, є формою, в якій зафіксована оперативно-розшукова інформація, а з іншого - така інформація є змістом матеріалів ОРД [1, с. 279].

Матеріали ОРД, як правило, визначаються як матеріально фіксовані джерела, що виникають у процесі здійснення опера- тивно-розшукових заходів, які містять фактичні дані про ознаки злочину, причетних до нього осіб, а також інші дані, що сприяють його розкриттю та можуть бути використані для прийняття рішень у кримінальному процесі [див., наприклад: 1, с. 275-276; 2, с. 52-53; 3, c. 184].

В абзаці другому ч. 2 ст. 99 КПК України законодавець визначив, що документами як джерелами доказів можуть бути матеріали, у яких зафіксовано фактичні дані про протиправні діяння окремих осіб та груп осіб, зібрані оперативними підрозділами 3 дотриманням вимог Закону України «Про оперативно-розшукову діяльність», за умови відповідності вимогам цієї статті. Щодо розуміння останнього нормативного припису слід зазначити, що ст. 99 КПК України стосується визначення загальних ознак процесуальних документів як джерел доказів у кримінальному провадженні. Але ця стаття не містить вичерпного переліку таких ознак. Вони також містяться, наприклад, у ст. 104-106, 236, 252 КПК України. Щоб відомості, які містяться у процесуальному документі, стали доказами у кримінальному провадженні, вони мають пройти через процедуру їх оцінки, в результаті якої суб'єкт доказування формує судження про те, що ці відомості є фактичними даними, які можуть виступати підставою для прийняття процесуальних рішень у кримінальному провадженні. Саме це зумовлює наше звернення для визначення вимог, яким мають відповідати матеріали ОРД задля використання ïx під час досудового розслідування злочинів, не тільки до нормативних приписів ст. 99 КПК України, а й в цілому до норм, які входять до правового інституту доказування у кримінальному провадженні. Такий підхід призводить до виділення таких вимог використання матеріалів ОРД в процесі доказування під час досудового розслідування злочинів, передбачених ст. 212 КК України:

1) вони мають бути зібрані оперативними підрозділами 3 дотриманням вимог Закону «Про оперативно-розшукову діяльність» та КПК України. Така вимога вказує на обов'язковість дотримання процесуальної форми одержання фактичних даних про обставини події злочину під час здійснення ОРД. Причому дотримання чи недотримання процесуальної форми, визначеної у кримінальному процесуальному законі, визначає допустимість чи недопустимість одержаних під час ОРД доказів. Це прямо випливає і 3 нормативних приписів п. 2, 7, 7-1 - 12, 17 ч. 1 ст. 8, а також ч. 2 ст. 8 Закону України «Про оперативно-розшукову діяльність», якими підстави, порядок прийняття про- 
цесуальних рішень щодо проведення та безпосереднього здійснення таких оперативнорозшукових заходів, як негласне обстеження публічно недоступних місць, житла чи іншого володіння особи, аудіо-, відеоконтроль особи, аудіо-, відеоконтроль місця, спостереження за особою, зняття інформації 3 транспортних телекомунікаційних мереж, електронних інформаційних систем, накладення арешту на кореспонденцію, здійснення iiï огляду та виїмки, установлення місцезнаходження радіоелектронного засобу, контрольована поставка та контрольована і оперативна закупка товарів, предметів та речовин, у тому числі заборонених для обігу, створення та використання заздалегідь ідентифікованих (помічених) або несправжніх (імітаційних) засобів, а також використання конфіденційного співробітництва під час їх проведення, визначені відповідно до норм глави 21 КПК. Відомчі інструкції, що регламентують проведення оперативно-розшукових заходів, затверджені, зокрема, наказами МФ, сформовані згідно з нормами Закону України «Про оперативно-розшукову діяльність» та КПК України. І в контексті нашого дослідження слід зазначити, що укладачі цих інструкцій у формуванні зразків бланків протоколів оперативно-розшукових заходів, настанов щодо їх складання та оформлення додатків до них правильно врахували положення не тільки статті 252 КПК, а й статей 104-106 КПК, тобто норм, які містять загальні вимоги до складання протоколів процесуальних дій та додатків до них;

2) у них мають бути зафіксовані фактичні дані про готування, вчинення ухилення від сплати податків, зборів (обов'язкових платежів) окремих осіб та груп осіб. Тут слід мати на увазі, що, як свідчать результати опитування співробітників оперативних підрозділів та слідчих, для визначення відповідності відомостей, які містяться у матеріалах ОРд, реальним подіям, що сталися, у 100 \% випадків співробітники оперативних підрозділів зазначають, що вони спираються на оцінку матеріалів оперативно-розшукової справи, а для слідчих основу такої оцінки та визначення фактичності у даних, які містяться у матеріалах ОРД, становлять виключно матеріали кримінального провадження. Відповідно, оціночні судження у свідомості співробітників оперативних підрозділів щодо належності та достовірності даних, які містяться у матеріалах ОРД, порівняно з такими ж судженнями слідчого, а так само й прокурора, а надалі сторони захисту, суду формуються на різній інформаційній основі. І це створює ситуації, коли не всі твердження співробітників оперативних підрозділів про доведеність тих чи інших фактів одержують своє підтвердження у кримінальному провадженні. Очевидно, що в контексті з'ясування належності та достовірності даних, які містяться у матеріалах ОРД, наданих для використання під час досудового розслідування, слід розглядати судження, сформовані слідчим та прокурором, які саме і є суб'єктами доказування на цій стадії кримінального провадження. Але це стосується тільки стадії досудового розслідування. Щодо судових стадій, то тут суд виступає ключовим суб'єктом оцінки доказів;

3) відомості про факти, які містяться у матеріалах ОРД, мають бути перевірені та підтверджені проведенням слідчих (розшукових), негласних слідчих (розшукових) та інших процесуальних дій під час досудового розслідування злочину, передбаченого ст. 212 КК України. Ця вимога генетично пов'язана із попередньою (щодо з'ясування належності та достовірності даних, джерелом яких є такі матеріали), і ії дотримання забезпечує збирання достатньої для прийняття процесуального рішення у кримінальному провадженні сукупності доказів. Без такої перевірки не спростувати розумні сумніви щодо доведеності тих чи інших фактів, які природньо виникають під час руху пошуково-пізнавальної діяльності у кримінальному провадженні від невідомого до відомого про обставини події злочину;

4) матеріали ОРД для використання ïх у доказуванні мають бути обов'язково розсекречені. Така умова прямо випливає з положень ч. 12 ст. 290 КПК України, згідно 3 якими якщо сторона обвинувачення не здійснить відкриття матеріалів відповідно до положень цієї статті, суд не має права допустити відомості, що містяться в них, як докази. Невиконання цієї вимоги вже неодноразово призводило до ухвалення Великою Палатою Верховного Суду та Касаційним кримінальним судом Верховного Суду рішень про визнання недопустимими доказами протоколів негласних слідчих (розшукових) дій та додатків до них у разі не розсекречення їх або не розсекречення процесуальних рішень щодо їх проведення до відкриття матеріалів кримінального провадження в порядку статті 290 КПК України [4; 5; 6]. За такої практики Верховного Суду не важко спрогнозувати, що якщо не будуть розсекречені оперативним підрозділом протокол оперативно-розшукового заходу, додатки до нього, клопотання щодо надання дозволу на його проведення слідчим суддею та процесуальне рішення щодо його проведення (постанова керівника оперативного підрозділу, прокурора, ухвала слідчого судді), то слідчий не 
зможе їх надати для ознайомлення стороні захисту, виконуючи вимоги ст. 290 КПК Україні, а отже, сторона обвинувачення і не зможе використати ці матеріали ОРД в суді як джерела доказів.

Поряд із загальними вимогами необхідно виділити і спеціальні для окремих документів, джерел доказів, які сформовані в результаті ОРД по досліджуваній категорії злочинів.

Протоколи оперативно-розшукових заходів та додатки до них безумовно визнаються документами - джерелами доказів, які за процесуальною формою відповідають протоколам процесуальних дій та додаткам до них, а також носіями інформації, на яких за допомогою технічних засобів зафіксовано процесуальні дії (п. 3 абзацу першого ст. 99 КПК України). Щодо цього джерела доказів необхідно зазначити, що додатками до нього відповідно до ч. 2 ст. 105 КПК України можуть бути спеціально виготовлені копії, зразки об'єктів, речей і документів, письмові пояснення спеціалістів, які брали участь у проведенні відповідної процесуальної дії, стенограма, аудіо-, відеозапис процесуальної дії, фототаблиці, схеми, зліпки, носії комп'ютерної інформації та інші матеріали, які пояснюють зміст протоколу. 3 числа наведених матеріальних об'єктів у контексті виходу за рамки обсягу поняття документа, про які йдеться у ст. 99 КПК України, виділяються копії чи зразки речей і документів, які можуть бути одержані під час проведення обстеження публічно недоступних місць, житла чи іншого володіння особи та є носіями слідів вчинення ухилення від сплати податків, зборів (обов'язкових платежів), передбаченого ч. 3 ст. 212 КК України. Це викликає питання на практиці та дає потенціальні підстави для сторони захисту оскаржувати допустимість як доказів таких матеріальних об’єктів. Однак копії чи зразки речей, документів, які можуть бути одержані під час такого оперативно-розшукового заходу, при системному тлумаченні нормативних приписів ст. 84-87, 99, 104-107, 252 КПК України без протоколу, в якому має бути зазначено, за допомогою якого технічного засобу, ким були вони одержані, а також ознаки цих копій чи зразків речей, документів, технічні носії, на яких вони зафіксовані та вилучення яких оформлено як додатки до такого протоколу, не будуть мати доказове значення у кримінальному провадженні. Їх формування як матеріальних об'єктів, які мають доказове значення у кримінальному провадженні, генетично пов'язане $з$ дотриманням процесуальної форми проведення та фіксування оперативно-розшукового заходу. Надалі у кримінальному провадженні копії чи зразки таких речей і документів піддаються огляду, за наявності підстав досліджуються під час проведення відповідних судових експертиз, пред’являються після ix розсекречення поряд 3 оригіналами цих речей і документів під час допиту свідкам, підозрюваним, тощо, тобто проходять через процедуру перевірки на предмет достовірності даних, які у них містяться.

Після реформи кримінального судочинства є проблема 3 використанням у кримінальному провадженні матеріалів, отриманих в результаті міжнародного співробітництва під час ОРД (ст. 5-1 Закону «Про оперативнорозшукову діяльність). Такі матеріали кореспондують 3 п. 2 абзацу першого ч. 2 ст. 99 КПК України. Відповідно до п. 20 ч. 1 ст. 8 Закону України «Про оперативно-розшукову діяльність» оперативний підрозділ в оперативнорозшукових справах має право звертатися у межах своїх повноважень із запитами про надання міжнародно-правової допомоги до правоохоронних органів інших держав та міжнародних правоохоронних організацій. Аналогічна можливість звернутися під час досудового розслідування щодо надання міжнародно-правової допомоги передбачена у Розділі IX КПК України. Ми вже зазначали, що законодавцем по суті визначена однакова процедура прийняття процесуальних рішень щодо оперативно-розшукових заходів, які $є$ однойменними з відповідними негласними слідчими (розшуковими) діями. І якщо в оперативно-розшуковій справі за запитом уповноваженого органу у сфері міжнародного співробітництва буде проведений уповноваженим органом правопорядку іноземної держави такий оперативно-розшуковий захід, то ми не вбачаємо проблем щодо визнання його протоколу та додатків до нього як джерел доказів у кримінальному провадженні. Однак, на жаль, чинні міжнародні договори про надання взаємної правової допомоги, які діють між Україною та іншими державами та укладалися як за умов дії КПК України 1960 року, так і КПК України 2012 року, не враховують той факт, що оперативно-розшукова діяльність тепер не може здійснюватися паралельно зі здійсненням кримінального провадження. Так, аналіз договорів про надання правової допомоги у кримінальних справах між Об'єднаними Арабськими Еміратами, Республікою Сенегал, Демократичною Соціалістичною Республікою ШріЛанка, Малайзією, Королівством Таїланд, які були укладені та ратифіковані Україною після 2012 року, свідчить про те, що підходи до формування їх змісту не змінилися. У них, як і раніше, визначається, що правова допомога охоплює: одержання свідчень та заяв від 
осіб; надання інформації, документів, записів та доказів; вручення документів; виконання запитів про розшук і вилучення; передачу осіб під вартою або сприяння явці інших осіб у запитуючу державу для надання показань; встановлення місцезнаходження осіб та предметів; заходи для виявлення, арешту та конфіскації доходів, одержаних злочинним шляхом; іншу правову допомогу, що відповідає цілям договору про надання правової допомоги. Основу проблеми становить те, що у договорах про надання правової допомоги йдеться про співробітництво у кримінальних, а не в оперативно-розшукових справах. Звісно, засади взаємності та ввічливості у міжнародних відносинах забезпечують можливість проведення оперативно-розшукових заходів уповноваженими органами правопорядку іноземних держав, однак, на наш погляд, за відсутності міжнародних угод, у яких прямо визначено право звертатися щодо одержання фактичних даних про обставини готування та вчинення злочину шляхом застосування особливих методів розслідування (термін «особливі методи розслідування» у міжнародному праві охоплюе як оперативно-розшукові заходи, так і негласні слідчі (розшукові) дії. - див. Рекомендації Комітету міністрів Ради Свропи державамчленам «Про «особливі методи розслідування» тяжких злочинів, у тому числі терористичних актів» N Rec (2005) 10 від 20 квітня 2005 року), надання міжнародної правової допомоги в оперативно-розшукових справах є вкрай ускладненим. Саме ця обставина визначається нами як причина того, що в міжнародному співробітництві в оперативнорозшуковій діяльності, зокрема, щодо ухилень від спати податків, зборів (обов'язкових платежів) домінує звернення із запитами про надання інформації через Інтерпол або напряму до уповноважених органів правопорядку іноземної держави щодо фізичних, юридичних осіб та обставин, які мають значення для провадження в оперативно-розшуковій справі. Відповіді на такі запити підпадають під ознаки документів, про які йдеться у п. 2 абзацу першого ч. 2 ст. 99 КПК України, та вони можуть бути використані під час досудового розслідування.

Під час здійснення провадження в оперативно-розшукових справах можуть проводитися ревізії та перевірки, матеріали яких підпадають під п. 4 абзацу першого ч. 2 ст. 99 КПК України. Для виявлення досліджуваної нами категорії злочинів проведення податкових перевірок взагалі є характерним. Відповідно, акти податкових перевірок, проведених в оперативно-розшукових справах оперативних підрозділів податкової міліції, при системному тлумаченні нормативних приписів абзацу ч. 1, 2 ст. 99 КПК України, п. 3 ч. 1 ст. 8 Закону України «Про оперативно-розшукову діяльність», ст. 348, 350 Податкового кодексу України, за умов відповідності податкової перевірки вимогам статті 78 Податкового кодексу України можуть бути документами джерелами доказів у кримінальних провадженнях.

\section{Висновки}

Таким чином, підсумовуючи проведене нами дослідження, ми дійшли таких висновків. По-перше, нормативні приписи, що визначають параметри, яким мають відповідати результати оперативно-розшукової діяльності для їх використання під час досудового розслідування ухилень від сплати податків, зборів (обов'язкових) платежів, містяться у нормах КПК України, Закону України «Про оперативно-розшукову діяльність», податкового законодавства, а також у міжнародно-правових актах у сфері протидії злочинності, які визначають підстави, порядок здійснення та оформлення дій, які можуть бути проведені в оперативно-розшукових справах щодо даної категорії злочинів, спрямованих на одержання фактичних даних про них. По-друге, системний аналіз оперативно-розшукового та кримінального процесуального законодавства свідчить, що матеріалами оперативно-розшукової діяльності, які можуть бути визнані документами - джерелами доказів у кримінальних провадженнях за ст. 212 КК України, є протоколи оперативно-розшукових заходів з додатками до них, документи, одержані в рамках міжнародного співробітництва у сфері оперативно-розшукової діяльності, та акти податкових перевірок, проведених на підставі даних оперативно-розшукової діяльності податкової міліції. Інші документи, які були одержані в рамках провадження по оперативно-розшуковій справі, можуть виступати як джерела орієнтуючої інформації для проведення процесуальних дій під час досудового розслідування цих злочинів. По-третє, для того щоб матеріали оперативно-розшукової діяльності могли бути використані в доказуванні у кримінальному провадженні: 1) вони мають бути зібрані оперативними підрозділами з дотриманням вимог Закону «Про оперативно-розшукову діяльність» та КПК України; 2) у них мають бути зафіксовані фактичні дані про готування, вчинення ухилення від сплати податків, зборів (обов'язкових платежів) окремими особами та групами осіб; 3) відомості про факти, які містяться у матеріалах ОРД, мають бути перевірені та підтверджені проведенням слідчих (розшукових), негласних 
слідчих (розшукових) та інших процесуальних дій під час досудового розслідування злочину, передбаченого ст. 212 КК України; 4) матеріали ОРД для використання їх у доказуванні мають бути обов'язково розсекречені.

\section{Список використаних джерел:}

1. Погорецький М.А. Функціональне призначення оперативно-розшукової діяльності у кримінальному процесі : монографія. Харків : Арсіс, ЛТД, $2007.576 \mathrm{c}$

2. Ігнатко В. Поняття матеріалів оперативнорозшукової діяльності, що використовуються в інтересах кримінального судочинства. Право України. 2004. № 11. С. 50-53.
3. Гаврик С.Ю. До визначення поняття «матеріали оперативно-розшукової діяльності». Боротьба з організованою злочинністю $i$ корупиією. 2010. № 23. С. 178-186.

4. Постанова Касаційного кримінального суду ВС від 29 квітня 2020 року у справі № 428/8931/15к. URL : http://www.reyestr.court.gov.ua/ Review/89082817 (дата звернення: 22.05.2020).

5. Постанова Великої Палати ВС від 16 січня 2019 року у справі № 751/7557/15-к. URL : http:// www.reyestr.court.gov.ua/Review/89082817 (дата звернення: 22.05.2020)

6. Ухвала Великої Палати Верховного Суду від 4.12.2019 у справі № 760/1788/16-к. URL : http:// www.reyestr.court.gov.ua/Review/86241657 (дата звернення: 22.05.2020).

Liubomyr Lonevskyi. Requirements for the results of operative-search activities for their use during the pre-trial investigation of tax, fees (mandatory payments) evasion

The article is based on the reflection of the needs of the practice of disclosure and investigation of tax, fees (mandatory payments) evasion regulation of operative-search activities of operational units of the tax police, in particular, its functional purpose in criminal proceedings, as well as conditions in which are the formation of sources of factual data on the circumstances of the crime, which are determined by the norms of the CPC of Ukraine 2012, identified and described the requirements for the results of operative-search activities for their use during the pre-trial investigation of tax, fees (mandatory payments) evasion. It is determined that the materials of operative-search activities, which can be recognized as documents as sources of evidence in criminal proceedings under Art. 212 of the Criminal Code of Ukraine, are protocols of operative-search measures with annexes to them, documents obtained in the framework of international cooperation in the field of operative-search activities, and acts of tax inspections conducted on the basis of operative-search activities of the tax police. Other documents obtained in the course of operative-search proceedings may serve as sources of indicative information for procedural actions during the pre-trial investigation of these crimes. It is stated that in order for the materials of operative-search activity to be used as evidence in criminal proceedings: 1) they must be collected by operative subdivisions in compliance with the requirements of the Law "On operative-search activity" and the CPC of Ukraine; 2) they must record the actual data on the preparation, evasion of taxes, fees (mandatory payments) of individuals and groups of persons; 3 ) information on the facts contained in the materials of operative-search activities must be verified and confirmed by investigative (search), covert investigative (search) and other procedural actions during the pre-trial investigation of the crime under Art. 212 of the Criminal Code of Ukraine; 4) materials of operative-search activity for their use in proof must be declassified.

Key words: results of operative-search activity, use of results of operative-search activity, pre-trial investigation of crimes, proving, proofs, evasion of taxes, fees (mandatory payments). 